\title{
IMPORTANCE OF LIFE CYCLE COSTING FOR CONSTRUCTION PROJECTS
}

\author{
Renata Schneiderova-Heralova \\ Czech Technical University in Prague, Czech Republic \\ heralova@fsv.cvut.cz
}

\begin{abstract}
The purpose of this paper is to highlight the role of life cycle costing in the preparation phase of construction projects, especially in the public sector. Life cycle costing is a method of economic analysis directed at all costs related to constructing, operating, and maintaining a construction project over a defined period of time. The main question for a sustainable design is how to put economic optimization into the early design stages. Design decisions made at this project phase are determining the whole life effectiveness of the building. In the early phase of construction projects, the enormous benefit of life cycle costing could be gained. The commonly used construction cost minimization approach should be substituted for life cycle costs optimization. In order to gain the maximum value for money, all costs incurred over the whole life span must be estimated. The optimization of the life cycle costs of a project, construction or equipment, is essential for the complex decision-making process. All in all, the solution with the minimum value of life cycle costs can be chosen. Public investors are required to meet the objectives of sustainable building, and together they face limited financial resources and frequently a very strict institutional framework including procurement procedures. The quantification of life cycle costs, when deciding on the construction, is required by the public sector in the Czech Republic. In addition, the amount of estimated life cycle costs has become a criterion in public tenders. This paper summarizes the experiences of valuating building designs in terms of life cycle costs. After identifying the public sector benefits, some significant difficulties are also summarized. Besides stressing the importance of life cycle costing, case studies of construction projects are provided.
\end{abstract}

Keywords: cost, life cycle costs, construction project, decision making.

\section{Introduction}

The construction business has lately accomplished a paradigmatic shift in its approach to structures delivery and the meeting of customer satisfaction. Where previously the design and construction teams put stress on delivering buildings at the lowest acquisition cost, a greater attentiveness to consider costs over the life cycle of the building have predominated. Clients currently require buildings that exhibit value for money over a long period. In short, these modifications have highlighted the significance of life cycle costing approaches to the design, construction and operation of buildings.

Buildings as results of construction projects are characterized by long lifespan and high costs. This fact is the reason why all decisions connected with construction project have long-term and significant impact [1]. Construction project investors often focused simply on the acquisition costs, when they were about to make decisions about such matters as the building design, equipment, energy systems. They frequently neglected future operation or maintenance costs [2]. As a result of the loss of a holistic view of true costs of a building, the cost-inefficient solution might be selected. Life cycle costs (LCC) in general consist of an initial investment (usually construction costs) and the follow-on costs (ordinary payments, i.e. energy, utilities, cleaning and maintenance, irregular costs for renewal or replacement), while some life cycle costing methods also include the costs of demolition [3]. Life cycle costing is often recommended as the method for finding cost-optimal solutions for product design. Life cycle costing is becoming the more frequent used tool in the design phase of buildings generally.

\section{Life cycle costing}

Life cycle costing is a method assisting in estimating of the total cost of ownership. The technique is able to help make decisions within building investment projects [4]. Life cycle costing is particularly useful for the estimating total costs in the early stage of a project [5]. The life cycle costing process usually includes the following steps:

- planning of the life cycle costing analysis (e.g. definition of objectives);

- selection and development of the life cycle costing model (e.g. cost breakdown structure, identifying data sources and contingencies);

- application of the life cycle costing model; 
- documentation and review of life cycle costing results.

An extensive research has been performed and a report published concentrated on life cycle costing [6]. Nevertheless, life cycle costing is not commonly used in Europe or in the USA. This method takes into consideration any other non-construction costs and income. Life Cycle Costs (LCC) represent the overall costs being spent during the building's whole life cycle. Their structure is presented in Fig. 1, as a part of the Whole Life Cost (WLC).

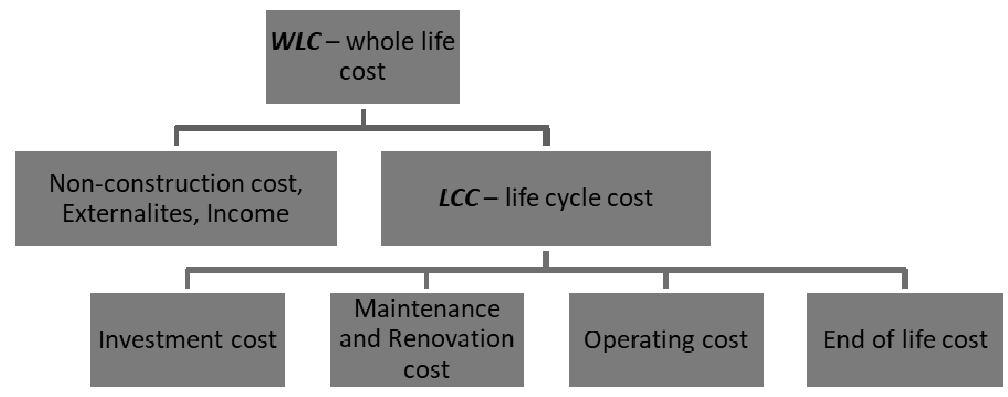

Fig. 1. Structure of Life Cycle Costs

\section{Decisions in the life cycle costing process}

Investors can sight the life cycle costing process of a building as a series of investment decisions. The procedure includes parallel and interrelated phases. A theoretical model (shown in Fig. 2) integrates six following steps $[7 ; 9 ; 13]$ :

- justification for investment requirements.

- conceptual development stage.

- design stage.

- production stage.

- operational stage.

- end of economic life stage.

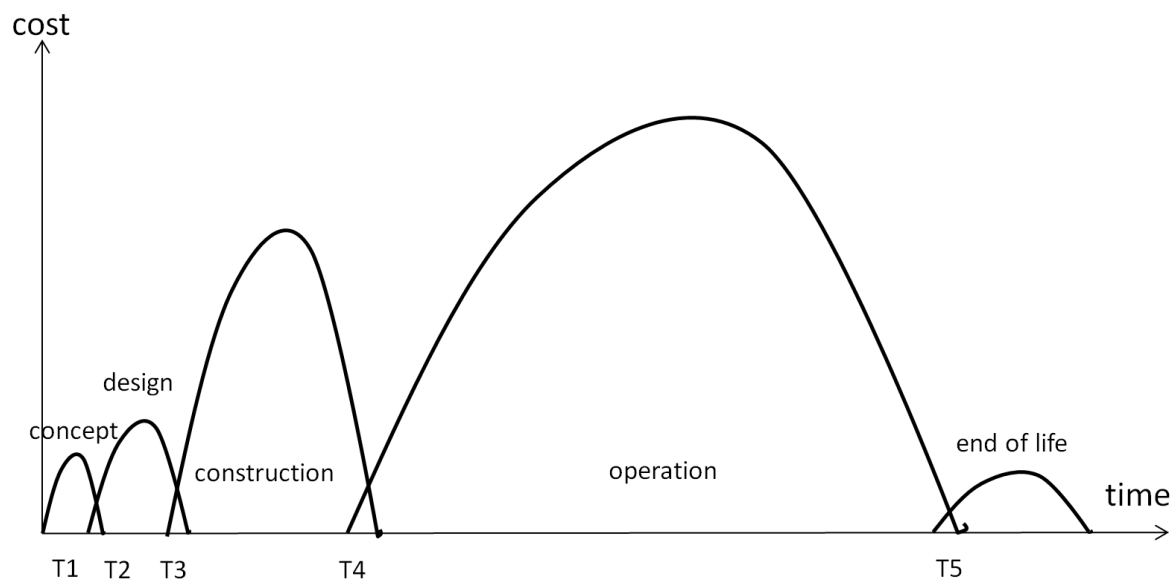

Fig. 2. Decisions in life cycle costing process

The horizontal axis represents a project phase and the time, at which key decisions and life cycle costing analysis need to be performed or updated. The vertical axis represents accumulative costs and costs of purchase and option within the life cycle of a construction project. This also can be seen as the acquisition cost of moving from one stage to another within the life span of a construction project. The utilization of a model should take place as early as possible and continue until the end life of the building.

The real series of decisions depends upon the specific project procurement route strategy. Some are following decisions, which could be assigned to the development process, whilst others might be connected with procurement and operational issues. The concept of depicting the life cycle of a building as a series of investment decisions is universal and could contain a diversity of miscellaneous 
development scenarios. Risk analysis and life cycle costing are conducted at the beginning and updated at the end of each stage of the construction project. Identifying, quantifying, responding and managing cost and risk at each investment stage of a construction project could be a useful framework for comprehension cost and risk strategies. However, it could be a useful framework for all decisions made thorough the life cycle of the building $[7 ; 8]$.

Decisions concerning the choice of the construction technology and construction materials are not any longer based entirely on technical and economic attitudes, but are becoming increasingly influenced by life cycle cost and environmental considerations. In fact, the capability to influence the outcomes of whole life ownership is enormous during the design phase. The types of material specified, the quality of the design and the contracting method have to be chosen directly upon operation and maintenance costs. By the way, the used procurement methods may have implications and great influence on life cycle costs. Operating, maintenance and rehabilitation costs of new and existing buildings amount to more than $80 \%$ of total life cycle costs [7]. It is well documented that the majority of decisions about operating, maintenance and rehabilitation costs are predetermined at the design stage. The opportunities to modify or influence decisions about operating, maintenance and rehabilitation costs decrease as projects progress through their natural process of development. Basically, it is crucial to establish a device at the design stage that brings together the life cycle costing, service life, environmental life cycle assessment, and risk associated with decisions taken at this stage.

\section{Case study: Office}

The office is currently based in a 40 year old office building, which is leased. The purchase of a new office building was considering for long time. The feasibility study, as a support for decision, was carried through [10]. A crucial part of the feasibility study was life cycle costing of alternatives, which were:

- Building of new facility - modern efficient certified building, spatially flexible, intelligent building system for heating, ventilation and air conditioning (HVAC), $17000 \mathrm{~m}^{2} \mathrm{BGF}$, and $62000 \mathrm{~m}^{3}$ enclosed area. Construction cost is taken from the author's database that includes prices of reference buildings. Rates of replacements and maintenance are given by studies on the reference buildings [11]. Salvage value of building is an estimate of the expected market value at the end of the study period.

- Purchase of current office - $16955 \mathrm{~m}^{2}$ BGF, $70000 \mathrm{~m}^{3}$ enclosed area. Purchase cost is equal to the bid price; operating cost is taken from the accounts. Maintenance and renewal cost is estimated on the basis of technical condition of the building. Salvage value of the building is an estimate of the expected market value [12] at the end of the study period.

The result of the feasibility study was a recommendation to build a new building. Total life cycle cost of this alternative is lower (see Table 1). The payback period based on the cost savings on the rental cost (620.000 EUR $\cdot$ year $\left.^{-1}\right)$ and operating cost (180.000 EUR $\cdot$ year $\left.^{-1}\right)$ was calculated. 26 years is an acceptable payback period for public sector. At present (i.e. March 2018), the design stage is already in progress.

Table 1

Life cycle costing of alternatives, study period 20 years

\begin{tabular}{|l|c|c|}
\hline \multicolumn{1}{|c|}{ Cost item, EUR } & Building of new base facility & Purchase of current seat \\
\hline Construction / Purchase cost & 21.050 .000 & 15.200 .000 \\
\hline Rental cost & $1.860 .000^{\mathrm{a})}$ & 0 \\
\hline Operating cost & $8.140 .000^{\mathrm{b}}$ & 11.220 .000 \\
\hline Maintenance and renewal cost & 3.590 .000 & 10.320 .000 \\
\hline Total & 34.640 .000 & 36.740 .000 \\
\hline Salvage value (estimate) & 15.000 .000 & 10.000 .000 \\
\hline Total LCC & 19.640 .000 & 26.740 .000 \\
\hline
\end{tabular}

a) rental cost in current seat $\left(620.000 \mathrm{EUR} \cdot\right.$ year $\left.^{-1}\right)$ during the realization of new seat (3 year)

b) operating cost in current seat (560.000 EUR $\cdot$ year $\left.^{-1}\right)$ during the realization of new seat ( 3 year), operating cost in new seat $380.000 \mathrm{EUR} \cdot$ year $^{-1}$ 


\section{Case study: Depository building for museum}

The project aims to build a new depository, which will allow relocation of all exhibits from the existing non-compliant repositories to new spaces with appropriate conditions. More than 150,000 exhibits of national and international importance will be saved, with reserves for the next 50 years, on an area of $4600 \mathrm{~m} 2$.

The proposed feasibility study demonstrated the economic sustainability of the construction project. An important part of the feasibility study was life cycle costing. The minimum, maximum and average levels of life cycle cost have been calculated (final recapitulation of the LCC is shown in Table 2). Construction cost is taken from the author's database that includes prices of reference depository buildings. Operational costs are estimated on the base of reference depository buildings. Rates of replacements and maintenance are given by studies on the reference buildings [10].

Life cycle costing of depository building (design), study period 20 years, EUR

Table 2

\begin{tabular}{|c|r|r|r|}
\hline Cost item & \multicolumn{1}{|c|}{ Minimum } & \multicolumn{1}{c|}{ Maximum } & \multicolumn{1}{c|}{ Average } \\
\hline Construction cost & 2880000 & 3600000 & 3240000 \\
\hline Operation cost & 1500000 & 2300000 & 1900000 \\
\hline Maintenance and renewal cost & 580000 & 720000 & 650000 \\
\hline Total LCC & 4960000 & 6620000 & 5790000 \\
\hline
\end{tabular}

The result of the study was a recommendation to initiate the preparation of a construction project and integrate the proposed investment plan in the budget of the Ministry of Culture of the Czech Republic. At present (i.e. March 2018), the conceptual development stage is already in progress.

\section{Discussion}

The life cycle costs calculation within deciding on the construction project is required by the public sector in the Czech Republic. In addition, the amount of the estimated life cycle costs has become a criterion in public tenders. Nevertheless, nobody knows how exactly to calculate life cycle costs. By the way, the question is who is to calculate life cycle costs. Is an architect or a consultant supposed to provide the life cycle calculation of the designed structure? All in all, the need for life cycle calculation hints at the lack of methodology. There are no directives. In fact, only case studies are available.

\section{Results}

Public investors are required to purchase sustainable buildings. However, they are confronted with limited financial resources and very strict institutional framework including procurement procedures. Once public investors have good directives, they might use them in proper way.

\section{Conclusions}

Life cycle costing should be performed as part of feasibility studies to find the most cost efficient solution, as part of all design stages. The optimization potential in the early design phases is significant and also cheap.

\section{Acknowledgements}

This paper was supported by the Grant Agency of the Czech Technical University in Prague, Grant No. SGS18/023/OHK1/1T/11.

\section{References}

[1] Ryghaug M., Sorensen KH. How energy efficiency fails in the building industry. Energy Policy, vol. 37, 2009, pp. 984-91.

[2] Jakob M. Marginal costs and co-benefits of energy efficiency investments. The case of the Swiss residential sector. Energy Policy, vol. 34, 2006, pp.172-87.

[3] Kovacic I., Zoller V. Building life cycle optimization tools for early design phases, Energy, vol. 92, 2015, pp. 409-419. 
[4] Flanagan R., Norman G. Life Cycle Costing: Theory and Practice, RICS, Surveyors publications Ltd. London, 1988.

[5] Bogenstatter U. Prediction and optimization of life-cycle costs in early design. Build. Res. Information, vol. 28(5-6), 2000, pp. 376-86.

[6] Langdon D. A common European methodology for Life Cycle Costing, European Commission, Davis Langdon Management Consulting, 2007.

[7] Boussabaine A., Kirkham R. Whole Life-cycle Costing, Risk and risk responses, Blackwell Publishing Ltd., Oxford, UK, 2004.

[8] Hromada E. Life Cycle Costing from the Investor's and Facility Manager's Point of View. In: HÁJEK, P., et al., eds. Central Europe towards Sustainable Building 2016 - Innovations for Sustainable Future. Central Europe towards Sustainable Building 2016 Innovations for Sustainable Future. Prague, 22.06.2016 - 24.06.2016. Praha: GRADA PUBLISHING. 1st edition, Prague, June 2016, pp. 1374-1380.

[9] Matějka P., Berka V. The evaluation methodology for Building Information Modeling in construction projects, CESB 2016 - Central Europe Towards Sustainable Building 2016: Innovations for Sustainable Future, pp. 845-852.

[10] Schneiderová Heralová, R. Life Cycle Costing as an Important Contribution to Feasibility Study in Construction Projects In: Procedia Engineering. Amsterdam: Elsevier. 2017, vol. 196, pp. 565-570.

[11] Karasek J., Veleba J. Development of nearly zero energy buildings and application of cost optimum. Business \& IT, 2017, Vol. VII(2), pp. 18-25, DOI: https://doi.org/10.14311/bit.2017.02.03.

[12] Hromada E. Analysis of the real estate market in the Czech Republic. Business \& IT, 2017, Vol. VII(1), pp. 32-37, DOI: https://doi.org/10.14311/bit.2017.01.05. 